GEFAD / GUJGEF41(2): 1273-1294(2021)

\title{
Otizm Spektrum Bozukluğu, Zihin ve Çoklu Yetersizliği Olan Çocukların Ebeveynlerinin Yaşam Doyum Düzeylerinin İncelenmesi*
}

\section{Investigation of Life Satisfaction Levels of Parents of Children with Autism Spectrum Disorder, Intellectual Disability and Multiple Disabilities}

\author{
Mehmet YAVUZ1 ${ }^{1}$, Pınar ŞAFAK ${ }^{2}$ \\ ${ }^{1}$ Trakya Üniversitesi, Özel Ĕ̈itim Bölümü, Zihin Engelliler Eğitimi Ana Bilim Dall. \\ mehmetyavuz23@hotmail.com \\ ${ }^{2}$ Gazi Üniversitesi, Özel Eğitim Bölümü, Çok Engelliler Eğitimi Ana Bilim Dalı. \\ apinar@gazi.edu.tr
}

\section{$\ddot{O} Z$}

Bu araştırmada Otizm Spektrum Bozukluğu, Zihin Yetersizliği ve Çoklu Yetersizliği Olan Çocukların Ebeveynlerinin yaşam doyum düzeylerinin çeşitli değişkenler açısından incelenmesi amaçlanmıştır. Araştırmada betimsel tarama modeli kullanılmıştır. Araştırmaya yetersizliği olan çocuğa sahip 256 ebeveyn katılmıştır. Araştırma verileri Diener, Emmons, Larsen ve Griffin (1985) tarafindan geliştirilmiş Dağll ve Baysal (2016) tarafindan Türkçeye uyarlanıp geçerlilik güvenirlilik çalışması yapılmış Yaşam Doyumu Ölçeği kullanılarak elde edilmiştir. Verilerin analizi için SPSS 24 versiyonu kullanılmış ve tek yönlü ANOVA Testi, Bağımsız Gruplar T Testi ve Tukey HSD Testi uygulanmıştır. Araştırma sonuçlarına göre ebeveynlerin yaşam doyum düzeyleri ortalama düzeyde, cinsiyet, yaş, çocuklarının yetersizlik türü ve cinsiyeti açısından anlaml farklılık gözlenmemiştir. Eğitim düzeyi değişkeni açısından ortaokul ile üniversite mezunları arasında üniversite mezunu olanlardan yana, gelir düzeyi değişkeni açısından 45015500 TL arası ile 6500 üstü arasında 6500 üstü olanlardan yana anlaml farklllı gözlenmiştir.

Anahtar Sözcükler: Yaşam doyumu, Yetersizliği olan çocuk, Otizm spektrum bozukluğu, Zihin yetersizliği, Çoklu yetersizlik

\footnotetext{
*Alıntılama: Yavuz, M. ve Şafak, P. (2021). Otizm spektrum bozukluğu, zihin ve çoklu yetersizliği olan çocukların ebeveynlerinin yaşam doyum düzeylerinin incelenmesi. Gazi Üniversitesi Gazi Ĕgitim Fakültesi Dergisi, 41(2), 1273-1294.
} 


\begin{abstract}
In this study, it was aimed to examine the life satisfaction levels of the parents of children with intellectual disabilities, autism spectrum disorders and multiple disabilities in terms of various variables. Descriptive survey model was used in the researchin which the parents of 256 disabled children participated. In the study, the Satisfaction with Life Scale, developed by Diener, Emmons, Larsen and Griffin (1985), was utilized. The scale, whose validity and reliability study were conducted by Dağll and Baysal (2016) was adapted to Turkish by the same researchers. SPSS 24 version was used for the analysis of research data. Besides, one-way ANOVA Test, Independent samples t-test and Tukey HSD Test were also employed to analyze the data in the study. According to the results of the research, while the life satisfaction level of the parents was found to be average, no significant difference was observed in terms of gender, age, the type of disability and gender of the children. As for the education level variable, a significant difference was observed in favor of university graduates when secondary school and university graduates were compared. In addition, regarding the income level, a significant difference was also observed in favor of above $6500 T L$ when the income level between 4501-5500 TL and over 6500 TL was compared.
\end{abstract}

Keywords: Life satisfaction, Children with disabilities, Autism spectrum disorders, Intellectual disability, Multiple disabilities

\title{
GIiRiş
}

Yaşam doyumu, kişinin kendi belirlediği kriterlere uygun olarak tüm yaşamını pozitif olarak algılamasıdır (Veenhoven, 1991). Cummins ve Nistico, (2002) göre ise yaşam doyumu bireyin yaşamını bir bütün olarak değerlendirmesi sonucunda elde ettiği öznel bir değerlendirmedir. Yaşam doyumu kişinin yaşamını nasıl algıladığı ile yakın ilişkilidir. Kişinin mutluluğa ulaşmada hedefleri ve bu hedeflere ulaşıp ulaşmadığ 1 kişinin öznel değerlendirmesi ile yakın ilişkilidir (Rask, Astedt-Kurki, Laippala, 2002). Kişinin yaşamdan arzuları ve o arzulara ulaşabilmesi arasındaki uyumsuzluk ne kadar az ise kişinin yaşam doyumunun o kadar yüksek olduğu kabul edilmektedir (Diener, Oishi ve Lucas, 2003). Köker (1991)'e göre ise yaşam doyumu kişinin yaşı, cinsiyeti, çalışma şartları, eğitim düzeyi, dini, inancı, ırkı, maaşı, aile yaşamı, sosyal yaşam ve kişilik özellikleri ile yakından ilişkilidir. Yaşam doyumu çeşitli değiş̧kenlerden etkilenmektedir. Bunlar: a) kişinin geliri, b) meslek ve sosyal statüsü, c) sahip olunan olanaklar ve sosyal hareketliliği, d) refah imkânları, e) ülke politikası ve f) kişinin çevresi, ailesi ve sosyal ilişkileridir (Appleton ve Song, 2008). 
Son yıllarda yaşam doyumunun incelendiği alanlardan biri de yetersizliği olan bireylerin aileleridir. Alanyazına baktığımızda yetersizliği olan bireylerin ebeveynlerinin yaşam doyum düzeyleri genel anlamda düşüktür (Akarsu, 2014; Can, 2015; Cho ve Kahng, 2015; Erdoğan, 2013; Genç, 2015; İnce ve Tüfekçi, 2015; Meyers ve Marcenko, 1989; Pruchno ve Patrick, 1999). Çünkü yetersizliği olan çocuk, ebeveynlerinin aile yaşamını büyük oranda etkilemekte, aileye ek yük ve sorunlar getirmektedir. Bu yük ve sorunlardan bazıları, yetersizliği olan çocuğun bakımı, ev rutinlerinin değişmesi ve aile üyelerinin rollerinin bozulması, ekonomik problemler, ek hastane masrafları, aylık gelirin azalmasıdır (Ohaeri, 2003). Bunların yanında aileye sosyal destek azalmakta, aile doyumu azalmakta, ebeveynlerde duygusal sorunlar oluşmakta, yaşam tarzları değişmektedir (Trute ve Hiebert-Murphy, 2002). Tüm bunlar ebeveynlerin öz-yeterlilik düzeylerinin azalmasına strese girmelerine bunun sonucunda da yaşam doyumlarının düşmesine neden olabilmektedir (Barlow, Powell ve Gilchrist, 2006; Çattık ve Aksoy, 2018; Williams, Cullen ve Barlow, 2005). Yaşam doyumu yüksek olan ebeveynler daha mutlu, sosyal yaşama daha açık, yaşamdaki problemlere karşı daha dayanıklı ve uygun tepki sergileyebilen, yaşam dolu, kişiler arası ilişkilerde daha olumlu, evlilikte sorun yaşamayan ve evlilikte oluşan sorunlarla kolayca başa çıkan bireylerdir (Sirgy ve diğerleri, 2006). Yaşam doyumunu etkileyen çeşitli faktörler bulunmaktadır. Bu faktörler olumlu kişilik algısı, günlük yaşamdan mutluluk duyma, hayatındaki hedeflere ulaşma düzeyi, yaşamını anlamlı olarak algılama, kendini fiziksel olarak iyi hissetme, olumlu sosyal ilişki kurma, ekonomik güvence olarak sayılabilir (Keser, 2005).

Alanyazında yetersizliği olan çocukların ebeveynlerinin yaşam doyum düzeylerini inceleyen çeşitli araştırmalara rastlanmaktadır. Akandere, Acar ve Baştuğ (2009) zihin yetersizliği olan (ZY) ve fiziksel yetersizliği olan çocukların ebeveynleriyle, Emerson, Hatton, Llewellyn, Blacker ve Graham (2006) ve Akarsu (2014) zihin yetersizliği olan çocukların anneleriyle, Ateş (2016) ve Hisoğlu (2018), Lu, Yang, Skora, Wang, Cai, YSun ve Li, (2015) otizm spektrum bozukluğu (OSB) olan çocukların ebeveynleriyle, Genç (2015) zihin yetersizliği olan çocukların ebeveynleriyle, Balkanlı (2008) OSB 
olan çocuğa sahip olan ve olmayan annelerle, Ekas, Lickenbrock ve Whitman (2010) ve Yıldırım (2020) OSB olan çocuğa sahip annelerle, Baykan, Baykan ve Naçar (2010) kronik hastalıklı çocukların ebeveynleriyle, Boztaş ve Tutkun (2017) özel gereksinimli çocuğu ebeveynleriyle, Can (2015) yetersizliği olan çocuğu olan ve olmayan ebeveynleriyle, Cho ve Kahng (2015) ve Çattık ve Aksoy (2018) gelişimsel geriliği olan çocukların ebeveynleriyle, Gebeyehu, Sahile ve Ayalew (2019), zihin yetersizliği olan çocukların bakıcılarıyla, Gülaldı, (2010) erken çocuklukta serebral palsili ve OSB olan çocukların anneleriyle, Kaner (2004), Kantar (2014) ve İnce ve Tüfekci (2015) yetersizliği olan çocuğa sahip ebeveynlerle, Ekiz Andiç (2018) çoklu yetersizliği olan görmeyen çocukların anneleriyle, Kahraman (2019) zihin ve ortopedik yetersizliği olan bireylerin ebeveynleriyle yaşam doyum düzeylerini inceledikleri çalışmalar bunlardan bazılarıdır. Yaşam doyumu bireyin tüm yaşam aktivitelerini etkileyen bir değişkendir. $\mathrm{Bu}$ sebeple yetersizliği olan çocuk ebeveynlerinin yaşam doyumları düzeyleri bilindiği takdirde eğer düşük ise arttırmak yüksek ise devamlı yüksek tutmak için gerekli uygulamalar geliştirebilir. Ebeveynlerin yaşam doyum düzeyleri de yüksek olunca hem kendileri hem de çocukları için daha nitelikli yaşam olanakları sunabileceklerdir. Bunun yanında alanyazında zihin yetersizliği, OSB ve çoklu yetersizliği olan bireylerin ebeveynlerinin yaşam doyum düzeylerini karşlaştıran araştırmaya rastlanmamıştır. Araştırma bu yönüyle de alanyazına katkı sağlayacağı düşünülmektedir. Bu amaçla bu çalışmada aşağıdaki sorulara cevap aranmıştır; Bu amaçla bu çalışmada OSB, zihin yetersizliği ve çoklu yetersizliği olan çocukların ebeveynlerinin;

1. Ebeveynlerinin yaşam doyum düzeyleri nedir?

2. Ebeveynleri yaşam doyum düzeyleri ebeveynlerin cinsiyeti, yaşı eğitim düzeyi, gelir düzeyi, çocuklarının yetersizlik türü ve yetersizliği olan çocuğun cinsiyetine göre anlamlı farklılık göstermekte midir? 


\section{YÖNTEM}

$\mathrm{Bu}$ bölümde araştırma yöntemi, katılımcılar, veri toplama araçları, verilerin toplanması ve verilerin analizi tanıtılacaktır.

\section{Araştırma Modeli}

$\mathrm{Bu}$ araştırmada OSB, zihin yetersizliği ve çoklu yetersizliği olan çocukların ebeveynlerinin yaşam doyum düzeylerinin çeşitli değişkenler açısından incelenmesi amaçlanmıştır. Bu sebeple bu araştırma nicel araştırma yöntemlerinden betimsel tarama modeline uygun olarak desenlemiştir. Betimsel tarama modeli ise geniş gruplar üzerinde yürütülen, gruptaki kişilerin bir olgu ve olayla ilgili görüşlerinin, tutumlarının incelendiği, olgu ve olayların tanımlanmaya çalışıldığı araştırmalardır (Karakaya, 2012).

\section{Katılımcılar}

Katılımcıların belirlenmesinde evren OSB, zihin yetersizliği ve çoklu yetersizliği olan çocukların ebeveynlerinden, ulaşılabilir evren ise Edirne ve İstanbul illeri içerisinde ikamet eden ebeveynlerden oluşmaktadır. Örneklem ulaşılabilir evren içerisinden uygun örnekleme yöntemiyle belirlenmiştir (Kılıç, 2012).

Tablo 1. Araştırmaya Katılan Ebeveynlere Ve Yetersizliği Olan Çocuklarına Ait Demografik Bilgiler

\begin{tabular}{llllcc}
\hline Anne-baba yaş & $\mathrm{N}$ & $\%$ & Gelir & $\mathrm{N}$ & $\%$ \\
\hline 30 yaş altı & 41 & $\% 16,02$ & $2501-3500 \mathrm{TL}$ & 97 & $\% 37,89$ \\
$31-40$ yaş & 49 & $\% 19,14$ & $3500-4500 \mathrm{TL}$ & 42 & $\% 16,41$ \\
$41-50$ yaş & 87 & $\% 33,98$ & $4501-5500 \mathrm{TL}$ & 46 & $\% 17,96$ \\
50 yaşüstü & 79 & $\% 30,86$ & $5501-6500 \mathrm{TL}$ & 32 & $\% 12,51$ \\
& & & 6501 TL ve üstü & 39 & $\% 15,23$ \\
\hline Ebeveyn Mezuniyeti & & & Çocuğun yetersizlik türü & & \\
\hline İlkokul & 68 & $\% 26,57$ & Zihin Yetersizliği & 116 & $\% 45,31$ \\
Ortaokul & 61 & $\% 23,83$ & Otizm Spektrum Bozukluğu & 105 & $\% 41,02$ \\
Lise & 76 & $\% 29,68$ & Çoklu Yetersizlik & 35 & $\% 13,67$ \\
Üniversite & 51 & $\% 19,92$ & & & \\
\hline Çocuğun cinsiyeti & & & Ebeveyn Cinsiyeti & $\mathrm{N}$ & \\
\hline Erkek & 149 & $\% 58,20$ & Erkek & 95 & $\% 37,20$ \\
Kız & 107 & $\% 41,80$ & Kadın & 161 & $\% 62,80$ \\
\hline
\end{tabular}




\section{Veri Toplama Araçları}

Verilerin toplanması için Demografik Bilgi Formu ve Yaşam Doyum Ölçeği kullanılmıştır.

\section{Demografik Bilgi Formu}

Araştırmacılar tarafından geliştirilen demografik bilgi formunda ebeveynleri cinsiyeti, yaşı, eğitim durumu, gelir düzeyi, çocuklarının yetersizlik türü ve çocuklarının cinsiyetini gibi demografik özelliklerini içeren sorulara yer verilmiştir.

\section{Yaşam Doyum Ölçeği}

Yaşam Doyum Ölçeği Diener ve diğerleri., (1985) tarafından geliştirilmiş, Dağlı ve Baysal (2016) tarafından Türkçeye uyarlanmıştır. Ölçeğin geçerlik ve güvenirlik çalışması yapılmıştır. Orijinal olarak beş maddeden oluşmaktadır ve beşli likert tipli bir ölçektir. Geçerlik-güvenirlik çalışması yapılan ölçek orijinal hali ile benzer olarak beş madde, beşli likert ve tek boyutlu şekilde oluşturulmuştur. Ölçeğin Cronbach Alpha katsayısı 0.88 ve test- tekrar test güvenirliği ise 0.97 olarak bulunmuştur. $\mathrm{Bu}$ araştırmanın Cronbach Alpha katsayısı 0.87 bulunmuştur.

\section{Verilerin Toplanması}

Araştırma verileri 2019-2020 eğitim öğretim yılı kasım aralık ayında toplanmıştır. Araştırma verileri Edirne, İstanbul illerinde özel eğitim ve rehabilitasyon merkezlerine devam eden yetersizliği olan bireylerin ebeveynlerinden toplanmıştır. Özel eğitim ve rehabilitasyon merkezleri bireysel olarak ziyaret edilerek kurum müdürleriyle görüşülmüştür. Kurum müdürlerine araştırmanın amacı anlatılmıştır. Kurum müdürünün gösterdiği bir odada ebeveynlerle yüz yüze görüşülmüştür. Yüz yüze görüşmede ebeveynlere araştırmanın amacı anlatılmıştır. Araştırmaya katılmaya gönüllü olan ebeveynlere ölçek verilmiş ve ölçeği nasıl dolduracakları anlatılmıştır. Velilere toplam 400 ölçek dağıtılmıştır. Geriye 261 ölçek gelmiştir. İncelenen ölçeklerden sadece 256 tanesi kullanılacak düzeyde olduğu görülmüş ve verilerin analiz 256 ölçek üzerinden yapılmıştır. 


\section{Etik Kurallara Uygunluk}

$\mathrm{Bu}$ araştırma verileri 2019-2020 eğitim öğretim yılı kasım aralık ayında toplanmıştır. Araştırma verileri Edirne, İstanbul illerinde özel eğitim ve rehabilitasyon merkezlerine devam eden yetersizliği olan bireylerin ebeveynlerinden toplanmıştır. Verilerin toplanması için araştırmacılar tarafından geliştirilen demografik bilgi formu ve Diener ve diğerleri., (1985) tarafından geliştirilen, Dağlı ve Baysal (2016) tarafından Türkçeye uyarlanana Yaşam Doyum Ölçeği kullanılmıştır. Yapılan bu araştırmada etik kurallara uyduğumu beyan ederim. Bu sebeple T.C. Trakya Üniversitesi Rektörlüğü Sosyal ve Beşeri Bilimler Araştırmaları Etik Kurulu Başkanlığının01.03.2021 tarih ve 25826 sayılı yazısı ile etik kurul yazısı Ek 1'de yer almaktadır.

\section{Verilerin Analizi}

Veriler bilgisayar ortamında IBM SPSS 24.0 paket programı ile gerçekleştirilmiştir. Veriler SPSS programına girilmiştir. Öncelikle verilere normallik testi uygulanmıştır. Basıklık ve çarpıklık değerlerine bakılmıştır. Verilerin normal dağılım gösterdiği gözlenmiştir. $\mathrm{Bu}$ sebeple verilerin analizinde, bağımsız örneklem t testi, tek yönlü ANOVA testi ve Tukey HSD Testi kullanılmıştır.

\section{BULGULAR}

Tablo 2. Ebeveynlerin Yaşam Doyum Düzeyleri

\begin{tabular}{lllll}
\hline Ölçek & $\mathrm{N}$ & $\mathrm{M}$ & $\overline{\mathbf{x}}$ & Ss. \\
\hline Yasam doyumu & 256 & 5 & 3,13 & 1,000 \\
\hline
\end{tabular}

Tablo 2'de görüldüğü gibi ebeveynleri yaşam doyum düzeyleri ortalama (x:3,13) düzeydedir.

Tablo 3. Ebeveynlerin Cinsiyet Değişkeni Açısından Yaşam Doyum Düzeyleri T Testi Sonuçları

\begin{tabular}{llccccc}
\hline & Cinsiyet & $\mathrm{N}$ & $\overline{\mathrm{X}}$ & $\mathrm{Ss}$ & $\mathrm{T}$ & $\mathrm{p}$ \\
\hline Yasam & Erkek & 95 & 3,205 & 1,023 &, 778 & \multirow{2}{*}{437} \\
doyumu & Kadin & 161 & 3,095 & 1,004 & & \\
\hline
\end{tabular}

Tablo 3'de görüldüğü gibi ebeveynlerin yaşam doyum düzeyleri cinsiyet değişkeni açısından anlamlı farklılık bulunmamaktadır $(\mathrm{F}=, 778, \mathrm{p}>0.05)$. 
Tablo 4. Ebeveynlerin Yaş Değişkeni Açısından Yaşam Doyum Düzeyleri Tek Yönlü ANOVA Sonuçları

\begin{tabular}{llccccc}
\hline & & & & & \\
& & $\mathrm{N}$ & $\overline{\mathrm{X}}$ & Ss & $F$ & $p$ \\
\hline Yasam doyumu & 30 yaş altı & 41 & 3,296 & 1,083 & 1,279 &, 282 \\
& 31-40 yaş & 49 & 3,211 &, 974 & & \\
& 41-50 yaş & 87 & 3,089 &, 979 & & \\
& 50 yaş üstü & 79 & 2,933 & 1,005 & & \\
\hline
\end{tabular}

Tablo 4'de görüldüğü gibi ebeveynlerin yaşam doyum düzeyleri yaş değişkeni açısından anlamlı farklılık bulunmamaktadır $(\mathrm{F}=1,279, \mathrm{p}>0.05)$.

Tablo 5. Ebeveynlerin Eğitim Düzeyi Değişkeni Açısından Yaşam Doyum Düzeyleri Tek Yönlü ANOVA Sonuçları

\begin{tabular}{lccccc}
\hline & $\mathrm{N}$ & $\mathrm{X}$ & $\mathrm{Ss}$ & $\mathrm{F}$ & $\mathrm{p}$ \\
\hline İlkokul & 68 & 3,098 & 1,104 & 2,767 &, 043 \\
Ortaokul & 61 & 2,946 & 1,053 & & \\
Lise & 76 & 3,075 &, 951 & & \\
Üniversite & 51 & 3,507 &, 817 & & \\
\hline
\end{tabular}

Tablo 5'de görüldüğü gibi ebeveynlerin yaşam doyum düzeyi eğitim düzeyi değişkeni açısından anlamlı farklılık bulunmaktadır $(\mathrm{F}=1,279, \mathrm{p}<0.05)$. Yaşam doyumu düzeyinin eğitim düzeyi değişkeni açısından hangi grupları arasında fark olduğunu belirlemek için yapılan Tukey HSD Testi uygulanmıştır. Yapılan Tukey HSD Testi sonucunda Ortaokul $(X=2,946)$ ile Üniversite $(X=3,507)$ mezunları arasında üniversite mezunu olanlardan yana anlamlı farklılık gözlenmiştir.

Tablo 6. Ebeveynlerin Gelir Düzeyi Değişkeni Açısından Yaşam Doyum Düzeyleri Tek Yönlü ANOVA Sonuçları

\begin{tabular}{lccccc}
\hline Gelir düzeyi & $\mathrm{N}$ & $\overline{\mathrm{X}}$ & $\mathrm{Ss}$ & $\mathrm{F}$ & $\mathrm{p}$ \\
\hline $2500-3500 \mathrm{TL}$ & 97 & 2,951 & 1,176 & 2,767 &, 043 \\
$3501-4500 \mathrm{TL}$ & 42 & 3,115 & 1,071 & & \\
$4501-5500 \mathrm{TL}$ & 46 & 2,871 &, 913 & & \\
$5501-6500 \mathrm{TL}$ & 32 & 3,270 &, 702 & & \\
6500 TL ve üstü & 39 & 3,557 &, 815 & & \\
\hline
\end{tabular}

Tablo 6'da görüldüğü gibi ebeveynlerin yaşam doyum düzeyi gelir düzeyi değişkeni anlamlı farklılık bulunmaktadır $(\mathrm{F}=1,279, \mathrm{p}<0.05)$. Yaşam doyumu düzeyinin gelir düzeyi değişkeni açısından hangi grupları arasında fark olduğunu belirlemek için yapılan Tukey HSD Testi uygulanmıştır. 4501-5500 TL (Türk Lirası) arası $(\overline{\mathrm{X}}=2,871)$ 
ile 6500 üstü $(\overline{\mathrm{X}}=3,557) \quad$ arasında 6500 üstü olanlardan yana anlamlı farklılık gözlenmiştir.

Tablo 7. Ebeveynlerin Çocuklarının Yetersizlik Türü Değişkeni Açısından Yaşam Doyum Düzeyleri Tek Yönlü ANOVA Sonuçları

\begin{tabular}{llccccc}
\hline & Çocuğun Yetersizlik & $\mathrm{N}$ & $\mathrm{X}$ & Ss & $\mathrm{F}$ & $\mathrm{p}$ \\
& Türü & & & & & \\
\hline Yasam & ZE & 116 & 3,128 &, 991 &, 071 &, 932 \\
doyumu & OSB & 105 & 3,114 & 1,022 & & \\
& Çoklu Yetersizlik & 35 & 3,193 & 1,064 & & \\
\hline
\end{tabular}

Tablo 7'de görüldüğü gibi ebeveynlerin yaşam doyum çocuklarının yetersizlik türü değişkeni açısından anlamlı farklılık bulunmamaktadır $(\mathrm{F}=, 071, \mathrm{p}>0.05)$.

Tablo 8. Ebeveynlerin Yetersizliği Olan Çocuğun Cinsiyet Değişkeni Açısından Yaşam Doyum Düzeyleri T Testi Sonuçları

\begin{tabular}{lllcccc}
\hline \multirow{3}{*}{ Yaşam Doyumu } & Cinsiyet & $\mathrm{N}$ & $\overline{\mathrm{X}}$ & $\mathrm{Ss}$ & $\mathrm{T}$ & $\mathrm{p}$ \\
\cline { 2 - 7 } & Erkek & 149 & 3,1496 & 1,04704 &, 349 &, 727 \\
\cline { 2 - 7 } & K1z & 107 & 3,1022 &, 95457 & & \\
\hline
\end{tabular}

Tablo 8'de görüldüğü gibi ebeveynlerin yaşam doyum düzeyleri cinsiyet değişkeni açısından anlamlı farklılık bulunmamaktadır $(\mathrm{F}=, 778, \mathrm{p}>0.05)$.

\section{SONUÇ, TARTIŞMA ve ÖNERILER}

Araştırma sonuçlarına göre ebeveynlerin yaşam doyumlarının ortalama düzeyde olduğu gözlenmiştir. Ebeveynlerin yaşam doyum düzeyleri arasında cinsiyet, yaş, çocuklarının yetersizlik türü ve cinsiyeti açısından anlamlı farklılık gözlenmemiştir. Eğitim düzeyi değişkeni açısından ortaokul ile üniversite mezunları arasında üniversite mezunu olanlardan yana, gelir düzeyi değişkeni açısından 4501-5500 TL arası ile 6500 üstü arasında 6500 üstü olanlardan yana anlamlı farklılık gözlenmiştir.

$\mathrm{Bu}$ araştırma sonuçlarına göre ebeveynlerin yaşam doyum düzeyleri ortalama düzeydedir. Alanyazında zihin, yetersizliği olan bireylerin ebeveynlerinin yaşam doyum düzeyini düşük bulan araştırma sonuçları bulunmaktadır (Akarsu, 2014; Can, 2015; Cho ve Kahng, 2015; Diener ve Emmons, 1985; Erdoğan, 2013; İnce ve Tüfekçi, 2015; 
Genç, 2015; Gülald1, 2010, Meyers ve Marcenko, 1989; Pruchno ve Patrick, 1999). Benzer şekilde Emerson, ve diğerleri, (2006) yetersizliği olan bireylerin ebeveynlerinin çok fazla stresli oldukları, buna karşın düşük düzeyde mutluluk yaşadıklarını ifade etmişlerdir. $\mathrm{Bu}$ çalışmayla paralel olarak Kheir ve diğerleri (2012) arkadaşları yetersizliği olan çocukların ebeveynlerinin yaşam kalitesini düşük olarak gözlemlemişlerdir. Bu araştırma sonuçlarına göre ebeveynlerin ortalama düzeyde yaşam doyumu sergilemelerine rağmen genel anlamda yetersizliği olan çocukların ebeveynlerinin yaşam doyumlarının düşük olduğu bilinmektedir. Bu durumun gerekçesi ise ebeveynler çocuklarının davranış problemleri, düşük sosyal destek gibi, yetersizliği olan çocuğun kendilerine fazladan yük getirmesi, düşük evlilik uyumu gibi sebeplerden dolayı yoğun stres ve depresyon yaşamaları olarak düşünülmektedir (Johnston ve diğerleri, 2003). Bu gibi durumlar ebeveynlerin yaşam doyumunu düşürmektedir.

$\mathrm{Bu}$ araştırma sonuçlarına göre ebeveynlerin yaşam doyum düzeylerinde cinsiyet değişkeni açısından anlamlı farklılık gözlenmemiştir. Alanyazında bu araştırma bulgularıyla paralel bulgulara rastlamaktadır (Baykan ve diğerleri, 2010; Diener, Diener ve Diener, 1995 Genç, 2015; Kaner, 2004; Pruchno ve Patrick, 1999). Ancak babaların yaşam doyumunun daha yüksek olduğunu bildiren araştırma sonuçları da bulunmaktadır (Shin, 2002; Balkanlı, 2008). Bu araştırma sonuçlarında göre ebeveynlerin yaşam doyum düzeylerinin cinsiyet değişkeni açısından anlamlı farklılık gözlenmesinin nedeni; genel anlamda alanyazında çelişkili bulgular bulunmasına rağmen, yetersizliği olan çocuğun bakım yükünün genelde annelerde olması şeklinde yorumlanmıştır. Buna karşın babaya da eve gelir getirme görevi düşmektedir (Cummings, Bayley ve Rie, 1996). Bu durum yetersizliği olan çocuk çiftlerin birbirlerine yakınlaşmış ve evlilik uyumlarını arttırmış olabilir (Özekes, Girli, Yurdakul ve Sarısoy, 1998). Böylelikle de yaşam doyumunu olumlu etkilemiş olabilir.

Ebeveynlerin yaşam doyum düzeyleri arasında yaş değişkeni açısından anlamlı farklılık gözlenmemiştir. Alanyazında ebeveynlerin yaş değişkeni açısından anlamlı fark gözlenmeyen araştırmalara rastlanmaktadır (Ekas, Lickenbrock ve Whitman, 2010; Genç, 2015). Buna karşın ebeveynlerin yaşı arttıkça yaşam doyumunun arttığını bildiren 
araştırmalar da bulunmaktadır (Akandere ve diğerleri, 2009; Boztaş ve Tutkun, 2017; Çattık ve Aksoy, 2018; Gülald1, 2010; Huang, Chang, Chi ve Lai 2014; Kantar, 2014; Lee ve diğerleri, 2009; Sarıkaya, 2011; Satılmış, 2020; Yıldırım, 2020). Alanyazında genç ebeveynlerde yaşam doyumunun yüksek olduğunu bildiren çalışmalar da bulunmaktadır (Can, 2015). Bu araştırma sonuçlarına göre ebeveynlerin yaşam doyum düzeylerinde yaş değişkeni açısından farklılık gözlenmemesinin nedeni yetersizliği olan çocuğun her yaş döneminde farklı problemleri ve yükleri aileye getirmesiyle açılanabilir.

$\mathrm{Bu}$ araştırma sonuçlarına göre ebeveynlerin eğitim düzeyi arttıkça yaşam doyum düzeyleri de artmaktadır. Alanyazında eğitim düzeyi arttıkça yaşam doyum düzeyi arttığını belirten araştırmalar bulunmaktadır. (Akandere ve diğerleri, 2014; 2009; Ateş, 2016; Baykan ve diğerleri, 2010; Diener, 2009; Genç, 2015; Gülaldı, 2010; Sarıkaya, 2011; Şener, 2017). Ancak yaşam doyumu ve eğitim düzeyi arasında ilişkinin bulunmadığını gösteren araştırmalar da bulunmaktadır (Akandere ve diğerleri, 2009; Balkanlı, 2008; Çattık, 2015). Can (2015) yaptığı araştırmada yetersizliği olan çocuğa sahip ve olmayan ebeveynlerden üniversite mezunları arasında yetersizliği olan çocuğa sahip ebeveynlerin yaşam doyumunun düşük olduğu gözlenmiştir. $\mathrm{Bu}$ araştırma sonuçlarına göre eğitim düzeyi arttıkça yaşam doyumunun arttığı yönünde bir sonuç bulgulanmıştır. Eğitim düzeyi arttıkça bireylerin iş bulma olanaklarının artacağı, ailelerine ve yetersizliği olan çocuklarına daha iyi eğitim, bakım ve tedavi olanakları sağlayabilecekleri ve bu nedenle de yaşam doyumunun yüksek olarak bulgulandığ şeklinde yorumlanmıştır.

$\mathrm{Bu}$ araştırma sonuçlarına göre gelir düzeyi yüksek olanlardan yana anlamlı farklılık gözlenmiştir. Alanyazında gelir düzeyi yüksek olanların yaşam doyumları yüksek olduğunu bildiren çalışmalar bulunmaktadır (Akandere ve diğerleri, 2009; Akarsu, 2014; Gebeyehu, Sahile ve Ayalew, 2019; Lu, Yang, Skora, Wang, Cai, Sun ve Li, 2015; Şener, 2017; Şener, Tutlu, Başgül, 2019; Yıldırım, 2020). Genç, (2015) yaptığı araştırmada çalışan ebeveynlerin yaşam doyum düzeyi yüksek olarak gözlenmiştir ve gelir düzeyi arttıkça yaşam doyumu artmaktadır (Genç, 2015). Can (2015) geliri yüksek 
ve yetersizliği olan çocuğu bulunmayan ebeveynlerin yaşam düzeyini yüksek gözlemiştir. Alanyazında yaşam doyumu ile gelir düzeyi arasında ilişki olmadığını bildiren çalışmalarda bulunmaktadır (Çattık, 2015). Gelir düzeyi insan yaşamını olumlu yönde etkileyen bir değişkendir. Gelir düzeyi yüksek olan bireyler kendilerine ve çocuklarına daha rahat yaşam olanakları sunmasıyla açıklanabilir.

$\mathrm{Bu}$ araştırma sonuçlarına göre ebeveynlerin yaşam doyum düzeyleri çocuğun e yetersizlik türü değişkeni açısından anlamlı farklılık göstermemiştir. Alanyazında çocuğun çoklu yetersizliği, zihin yetersizliği, OSB veya çoklu yetersizliği olmasını karşılaştıran araştırmaya rastlanmamıştır. Buna karşın Genç (2015) yaptığı araştırmada zihin yetersizliğinin düzeyine ve ek yetersizliğe göre anlamlı farklılık gözlememiştir. Benzer şekilde çocuğun yetersizlik türüne göre farklılık gözlenmediğini belirten araştırmalar bulunmaktadır (Çattık, 2015; Genç, 2015). Balkanlı (2008) yaptığı araştırmada OSB olan çocuğa sahip ebeveynlerle olmayanlar arasında fark gözlememiştir. Yıldırım (2020) annelerin yaşam doyumlarında OSB’nin algılanan ağırlık derecesine göre anlamlı bir farklılık gözlenmemiştir. Can (2015) yetersizliği olan çocuğa sahip olan ve olmayan ebeveynlerin yaşam doyum düzeyini eşit olarak gözlemiştir. Bunlara karşın Küçük ve Alemdar (2017) fiziksel yetersizliği olan çocukların annelerinin yaşam doyumunu daha yüksek olarak gözlemişlerdir. Endokrin sistem hastalı̆̆ olan çocuğa sahip ebeveynlerin yaşam doyum düzeyleri nörolojik hastalıklı çocukları olan ebeveynlerden daha yüksek gözlenmiştir (Baykan ve diğerleri, 2010). Şener, Tutlu, Başgül'e (2019)'e göre gelişimsel geriliği olan çocuğa sahip ebeveynlerin yaşam doyum düzeyi, gelişimsel geriliği olan çocuğa sahip olmayanlardan düşüktür. Aysan ve Özben (2007), yetersizliği olan çocuğu bulunmayan annelerin yaşam kalitesinin daha yüksek olduğunu gözlemişlerdir. Bu araştırma sonuçlarına göre çocuğun OSB, zihin yetersizliği ve çoklu yetersizliği olması ebeveynlerin yaşam doyumunun farklılaşmaması, yetersizlik türlerinin ebeveynleri eşit oranda etkilemesi olarak yorumlanabilir.

$\mathrm{Bu}$ araştırma sonuçlarına göre ebeveynlerin yaşam doyum düzeyi yetersizliği çocuğun cinsiyeti açısından anlamlı farklılık göstermemiştir. Alanyazında bu araştırma 
bulgularıyla benzer araştırma bulgularına rastlanmaktadır. (Acar, 2009; Baykan ve diğerleri 2010; Hisoğlu, 2018; Kahraman, 2019; Kaner, 2004; Kantar, 2014). Buna karşın Akandere ve diğerleri (2009) kız çocuğuna sahip annelerin yaşam doyum düzeylerinin, kız çocuğuna sahip babaların yaşam doyum düzeylerinde yüksek olarak gözlemiştir. $\mathrm{Bu}$ araştırmada ebeveynlerin yaşam doyum düzeyi çocuğun cinsiyeti açısından anlamlı farklılık göstermemesinin gerekçesi ise ebeveynlerin çocuklarının cinsiyetine bakmaksızın onları sahiplenmeleri ile açıklanabilir.

$\mathrm{Bu}$ araştırmanın belli sınırlılıkları bulunmaktadır. Öncelikle bu araştırma Edirne ve İstanbul illeriyle sınırlıdır. Bunun yanında çocukları özel eğitim ve rehabilitasyon merkezlerine devam eden, bu araştırmaya katılmayı kabul eden OSB, zihin yetersizliği ve çoklu yetersizliği olan çocukların ebeveynleriye sınırlıdır. İleri araştırmalara yönelik olarak, bu araştırmanın farklı illerde ve farklı yetersizlik gruplarıyla gerçekleştirilmesi önerilebilir. Bunun yanından farklı yetersizlik gruplarından çocuklara sahip ebeveynlerle olağan gelişim gösteren çocukların ebeveynlerinin yaşam doyumlarının karşılaştırıldığı araştırmalar yapılabilir. İleriki araştırmalarda karma desenle araştırmalar planlanabilir veya yaşam doyumu, evlilik uyumu, sosyal destek algılaması gibi değişkenler çalışılabilir. Bunların yanında ebeveynlerin yaşam doyum düzeylerini destekleyecek programlar geliştirilebilir. 


\section{KAYNAKLAR}

Acar, M. (2009). Zihinsel ve fiziksel özürlü çocuğa sahip anne ve babaların yaşam doyumu ve umutsuzluk düzeylerinin incelenmesi. (Yayımlanmamış Yüksek lisans tezi). T.C. Selçuk Üniversitesi Sağlık Bilimleri Enstitüsü, Konya.

Akandere, M., Acar, M., \& Baştuğ, G. (2009) Zihinsel ve fiziksel engelli çocuğa sahip anne ve babaların yaşam doyumu ve umutsuzluk düzeylerinin incelenmesi. Selçuk Üniversitesi Sosyal Bilimler Dergisi, 22, 23-32.

Akarsu, Ö. (2014). Zihinsel yetersiz çocukların aile yükü, özbakım becerileri, annelerinin yaşam doyumu ve etkileyen faktörler. (Yayımlanmamış yüksek lisans tezi), Trakya Üniversitesi, Sağlık Bilimleri Enstitüsü, Edirne.

Appleton, S., \& Song, L. (2008). Life satisfaction in urban China: Components and determinants. World Development, 36(11), 2325-2340.

Ateş, G. E. (2016). Rehabilitasyon merkezlerinde eğitim alan otizm tanısı almış olan çocuklara sahip ebeveynlerin yaşam doyumunun, aile işlevlerinin ve öğrenilmiş güçlülüğ̈̈nün incelenmesi. (Yayımlanmamış yüksek lisans tezi). Beykent Üniversitesi, Sosyal Bilimler Enstitüsü, İstanbul.

Aysan, F., \& Özben, Ş. (2007). Engelli çocuğu olan anne babaların yaşam kalitelerine ilişkin değişkenlerin incelenmesi. Dokuz Eylül Üniversitesi Buca Eğitim Fakültesi Dergisi, 22, 1-6.

Balkanlı, N. (2008). Otistik çocuğu olan ve olmayan annelerde yaşam kalitesi, yaşam doyumu ve umutsuzluk düzeyleri arasındaki ilişkinin incelenmesi. (Yayımlanmamış yüksek lisans tezi). Maltepe Üniversitesi, Sosyal Bilimler Enstitüsü, İstanbul.

Barlow, J., Powell, L., \& Gilchrist, M. (2006). The influence of the training and support programme on the self-efficacy and psychological well-being of parents of children with disabilities: a controlled trial. Complementary Therapies in Clinical Practice, 12, 55-63.

Baykan, Z., Baykan, A., \& Naçar, M. (2010). Kronik hastalıklı çocukları olan ailelerin yaşam doyumlarının incelenmesi. Yeni Tıp Dergisi, 27(3), 174-177.

Bilge, A., Buruntekin, Demiral, O., Özer, N. G., Keleş, B., Yalçın, E., Tavukçu, G. Kıray, A. \& Siviloğlu, T. (2014). Engelli yakınlarına verilen stresle baş etme ve yaşam doyumlarını arttırma eğitiminin etkinliğinin belirlenmesi. Gümüşhane Üniversitesi Să̆llk Bilimleri Dergisi, 3(1), 611-618.

Boztaş, Z., \& Tutkun, Ö. F. (2017). Özel gereksinimli çocuğu olan anne-babaların yaşam doyumu düzeyi. Akademik Sosyal Araştırmalar Dergisi, 5(50), 390-399. 
Can, F. G. (2015). Engelli çocuğu olan ve olmayan ebeveynlerin evlilik uyumu yaşam doyumu ve etkileyen faktörler. (Yayımlanmamış yüksek lisans tezi). Atatürk Üniversitesi, Sağlık Bilimleri Enstitüsü, Erzurum.

Cho, S., \& Kahng, S. K. (2015). Predictors of life satisfaction among caregivers of children with developmental disabilities in South Korea. Asian Social Science, 11(2), 154-166. doi:10.5539/ass.v11n2p154

Cummings, S. T., Bayley, H. C., \& Rie, H. E. (1996) Effect of the child's defiency on the mother: A study of mothers of mentally retarded, chronically ill and neurotic children , American Journal of Orthopsychiatry, 36, 595-608.

Cummins, R. A. \& Nistico, H. (2002). Maintaining Life Satisfaction: The Role of Positive Cognitive Bias. Journal of Happiness Studies, 3, 37-69.

Çam, O., \& Özkan, Ö. (2009). Otistik çocuk sahibi ailelerin yaşam kalitelerinin incelenmesi. Öz-Veri Dergisi, 6(2), 1425-1439.

Çattık, M. (2015). Gelişimsel yetersizliği olan çocukların ebeveynlerinin sosyal destek ve öz yeterlilik düzeyleri arasındaki ilişkinin incelenmesi. (Yayımlanmamış yüksek lisans tezi). Anadolu Üniversitesi Eğitim Bilimleri Enstitüsü, Eskişehir.

Çattık, M., \& Aksoy, V. (2018). Gelişimsel yetersizliği olan çocukların ebeveynlerinin sosyal destek, öz yeterlik ve yaşam doyum düzeyleri arasındaki ilişkinin incelenmesi. Eğitim ve Bilim, 43(195), 65-77

Dağlı, A., \& Baysal, N. (2016). Yaşam Doyum Ölçeğinin Türkçe'ye uyarlanması: Geçerlilik ve Güvenirlik Çalışması. Elektronik Sosyal Bilimler Dergisi, 15(59). doi:10.17755/esosder.75955.

Dereli, F., \& Okur S. (2006). Engelli çocuğa sahip ailelerin depresyon durumunun belirlenmesi. Yeni Tip Dergisi,25(3), 164-168.

Diener, E., \& Emmons, R. (1985). The İndependence of Positive and Negative Affect. Journal of Personality and Social Psychology, 47(5), 1105.

Diener, E., Diener, M., \& Diener, C. (1995). Factors prediciting the subjective wellbeing of nations. Journal of Personality and SocialPsychology, 69(5), 851-864.

Diener, E., Emmons, R. A., Larsen, R. J. \& Griffin, S. (1985). The satisfaction with life scale. Journal of Personality Assessment, 49 (1), 71-75.

Diener, E., Oishi, S., \& Lucas, R. E. (2003). Personality, culture, and subjective wellbeing: Emotional and cognitive evaluations of life. Annual Review of Psychology, 54(1), 403-405.

Ekas, N. V., Lickenbrock, D. M., \& Whitman, T. L. (2010). Optimism, social support, and well-being in mothers of children with autism spectrum disorder. Journal of Autism and Developmental Disorders, 40(10), 1274-1284.

Ekiz Andiç, H. (2018). Çoklu yetersizlikten etkilenmiş görmeyen çocukların annelerinin aile yaşam kalitesi ve yaşama yönelik algılarının incelenmesi. (Yayınlamamış yüksek lisans tezi). Gazi Üniversitesi, Eğitim Bilimleri Enstitüsü, Ankara. 
Emerson, E., Hatton, C., Llewellyn, G., Blacker, F., \& Graham, H. (2006). Socio economic position, household, composition, health status and indicators of the well being of mothers of children with and without intellectual disabilities. Journal of Intellectual Disability Research, 50(12), 862-873.

Erdoğan, B. (2013). Evde bakım hizmeti alan özürlü bireye sahip ailelerin sosyoekonomik durumlarının incelenerek, umutsuzluk ve yaşam doyum düzeylerinin belirlenmesi. (Yayınlamamış yüksek lisans tezi). Selçuk Üniversitesi, Sağlık Bilimleri Enstitüsü, Konya.

Gebeyehu, F., Sahile, A., \& Ayalew, M. (2019). Burden, social support, and life satisfaction among caregivers of children with intellectual disability: the case of Felege Abay and Shembt primary schools, Bahir Dar, Ethiopia. International Quarterly of Community Health Education, 39(3),147-153. doi: 10.1177/0272684X18819974.

Genç, H. (2015). Zihinsel engelli çocuklara sahip anne ve babaların yaşam doyumlarının ve aleksitimik düzeylerinin incelenmesi. (Yayımlanmamış yüksek lisans tezi), Gaziosmanpaşa Üniversitesi Eğitim Bilimleri Enstitüsü, Tokat.

Gülaldı, D. (2010). Erken çocuklukta serebral palsili ve otistik çocuk annelerinin ebeveyn stres düzeylerinin yaşam doyumlar ile ilişkisinin incelenmesi. (Yayımlanmamış yüksek lisans tezi). Maltepe Üniversitesi, Sosyal Bilimler Enstitüsü, İstanbul.

Hastings, R. P. \& Brown, T. (2002). Behavior problems of children with autism, parental self-efficacy, and mental health. American Journal on Mental Retardation, 3(107), 222-232.

Hisoğlu, A. (2018). Otizm spektrum bozukluğu tanılı çocukların ebeveynlerinde algılanan sosyal destek ve problem çözme becerilerinin yaşam doyumuna etkisi. (Yayımlanmamış yüksek lisans tezi). Üsküdar Üniversitesi, Sosyal Bilimler Enstitüsü, İstanbul.

Huang, Y. P., Chang, M. Y., Chi, Y. L., \& Lai, F. C. (2014 ). Health-related quality of life in fathers of children with or without developmental disability: The mediating effect of parental stress. Quality of Life Research, 23(1), 175-183. doi:10.1007/s11136-013-0469-7.

İnce, Z. E., \& Tüfekci, F. G. (2015). Engelli çocuğu olan ebeveynlerde evlilik uyumu ve yaşam doyumunun değerlendirilmesi ve etkileyen faktörlerin belirlenmesi. Gümüşhane Üniversitesi Sağllk Bilimleri Dergisi, 4(1), 102-112.

Johnston, C., Hessl, D., Blasey, C., Eliez, S., Erba, H., Dyer-Friedman, J., ... \& Reiss, A. L. (2003). Factors associated with parenting stress in mothers of children with fragile X syndrome. Journal of Developmental \& Behavioral Pediatrics, 24(4), 267-275. 
Kahraman, H. (2019). Zihinsel ve ortopedik engelli bireylerin ebeveynlerinde engellilerin hakları hakkında bilgi sahibi olmanın yaşam doyumu ve ebeveynlerin stresle başa çıkma tutumları ile ilişkisi. (Yayımlanmamış yüksek lisans tezi). Üsküdar Üniversitesi, Sosyal Bilimler Enstitüsü, İstanbul.

Kaner, S. (2004). Engelli çocukları olan ana babaların algıladıkları stres, sosyal destek ve yaşam doyumları. Ankara, Ankara Üniversitesi Bilimsel Araştırma Projeleri. http://hdl.handle.net/20.500.12575/68118 adresinden erişilmiştir.

Kantar, Ö. (2014). Engelli çocuğu olan ebeveynlerde bilişsel değerlendirmenin, gelişme-büyümenin yaşam doyumu ile ilişkisi. (Yayımlanmamış yüksek lisans tezi). İstanbul Bilim Üniversitesi, Sosyal Bilimler Enstitüsü, İstanbul.

Karakaya, İ. (2012). Bilimsel araştırma yöntemleri. A. Tanrı̈ğgen (Ed.) Bilimsel araştırma yöntemleri (s. 57-83) içinde. Ankara: Anı.

Keser, A. (2005). İş doyumu ve yaşam doyumu ilişkisi: otomotiv sektöründe bir uygulama. Çalışma ve Toplum, Ekonomi ve Hukuk Dergisi, 4(7). 77-96.

Kheir, N., Ghoneim, O., Sandridge, A.L., Al İsmail, M., Hayder, S. \& Al Rawi, F. (2012). Quality of life of caregivers of children with autism in Qatar. Autisim. 16(3), 293-298

Kılıç, S. (2013). Örnekleme yöntemleri. Journal of Mood Disorders, 3(1) 44-6.

Köker S. (1991) Normal ve Sorunlu ergenlerin yaşam doyumu düzeylerinin karşılaştırılması. (Yayımlanmamış Yüksek Lisans Tezi), Ankara: Ankara Üniversitesi Sosyal Bilimler Enstitüsü.

Küçük, E., \& Alemdar, D. K. (2017). Life satisfaction and psychological status of mothers with disabled children: a descriptive study. Community Mental Health Journal, 54(1),102-106. doi: 10.1007/s10597-017-0135-6

Lee, G. K., Lopata, C., Volker, M. A., Thomeer, M. L., Nida, R. E., Toomey, J. A., ... \& Smerbeck, A. M. (2009). Health-related quality of life of parents of children with high-functioning autism spectrum disorders. Focus on Autism and Other Developmental Disabilities, 24(4), 227-239. doi:10.1177/108835760934737127-239.

Lu, M., Yang, G., Skora, E., Wang, G., Cai, Y., Sun, Q., \& Li, W. (2015). Self-esteem, social support, and life satisfaction in Chinese parents of children with autism spectrum disorder. Research in Autism Spectrum Disorders, 17, 70-77.

Meyers, J.C., \& Marcenko, M. O., (1989). Impact of a cash subsidy program for families of children with severe developmental disabilities. Mental Retardation, 27(6), 383-387.

Mutlu, A., Akmeşe, P., \& Günel, M. (2010). Değişik özür seviyesindeki serebral palsili çocukların annelerinin depresyon düzeyleri farklı mıdır? Yeni Tıp Dergisi 27, 87-92.

Myers, D. G., \& Diener, E. (1995). Who is happy?. Psychological Science, 6(1), 10-19. 
Ohaeri, J. U. (2003). The burden of caregiving in families with a mental illness: a review of 2002. Current Opinion in Psychiatry, 16(4), 457-466.

Özdevecioğlu M. \& Aktaş A. (2007). Kariyer bağlılı̆̆1, mesleki bağlılık ve örgütsel bağlılığın yaşam tatmini üzerindeki etkisi: İş-aile çatışmasının rolü. Erciyes Üniversitesi İktisadi ve İdari Bilimler Fakültesi Dergisi, 28, 1-20.

Özekes, M., Girli, A., Yurdakul, A., \& Sarısoy, M. (1998). Evlilik ilişkisinde engelli çocuğa sahip olmanın rolü. Sözlü Bildiri. X. Ulusal Psikoloji Kongresi, Ankara Üniversitesi, Ankara.

Pruchno, R., \& Patrick, J. H. (1999). Mothers and fathers of adults with chronic disabilities. Research on Aging, 21(5), 682-713.

Rask, K, Astedt-Kurki, P. \& Laippala, P. (2002), Adolescent subjec-tive well-being and realized values. Journal of Advanced Nursing, 38, 254-263.

Roach, M. A., Ormond, G. I., \& Barratt, M. S. (1999). Mothers and fathers of children with Down Syndrome: Parental stress and involvement in children. American journal of mental retardation, 104, 422-436.

Sarıkaya, S. (2011). Zihinsel engelli çocuğu olan ebeveynlerin stresle başa çıkma düzeylerinin ve yaşam doyumlarının incelenmesi. (Yayımlanmamış yüksek lisans tezi). Dokuz Eylül Üniversitesi, Eğitim Bilimleri Enstitüsü, İzmir.

Satılmış, S. (2020). Otizm spektrum bozukluğu tanısı almış çocukların annelerinde psikolojik dayanıklılık, yaşam doyumu ve depresyon arasındaki ilişkinin incelenmesi. (Yayımlanmamış yüksek lisans tezi). Yakın Doğu Üniversitesi, Sosyal Bilimler Enstitüsü, Kıbris.

Seltzer, M. M., \& Krauss, M. W. (1989). Aging parents with adult mentally retarded children: Family risk factors and sources of support. American Journal on Mental Retardation, 94, 303-312.

Shin, J. Y. (2002). Social support for families of children with mental retardation: comparison between Korea and the United States. Mental Retardation, 40(2),103-118.

Sirgy, J. M., Michalos, A. C., Ferris, A., Easterlin, R., Patrick, D., \& Pavot, W. (2006). The quality-of-life (QoL) research movement: Past, present, and future. Social Indicators Research, 76, 343-466.

Şener, Ö (2017). 3-6 yaş arası gelişim geriliği olan çocukların annelerinin suçluluk utanç düzeyleri ve yaşam doyum düzeyleri arasındaki ilişkinin incelenmesi. (Yayımlanmamış yüksek lisans tezi). Hasan Kalyoncu Üniversitesi, Sosyal Bilimler Enstitüsü, Gaziantep.

Şener, Ö., Tutlu, M. G., \& Başgül, Ş. S. (2019). Gelişim geriliği olan çocukların annelerinin suçluluk ve utanç düzeyleri ile yaşam doyum düzeyleri arasındaki ilişki. Uluslararası Erken Çocukluk Eğitimi Çalışmaları Dergisi, 4(1), 36-55. 
Trute, B., \& Hiebert-Murphy. D. (2002). Family adjustment to childhood developmental disability: a measure of parent appraisal of family impacts. Journal of Pediatric Psychology 27(3), 271-280.

Turnbull, A. P., \& Turnbull, H. R. (1995). Families, professionals, and exceptionality. NewJersey: Merril.

Veenhoven, R. (1991). Is Happiness relative? Social Indicators Research, 24(1), 1-34.

Williams, H. L., Cullen, L. A. \& Barlow, J. H. (2005). The psychological well-being and self-efficacy of carers of children with disabilities following attendance on a simple massage training and support programme: A 12-month comparison study of adherers and non-adherers. Complementary Therapies in Medicine, 13 (2), 107-114. doi:10.1016/j.ctim.2005.03.007

Yıldırım, M. (2020). Otizm spektrum bozukluğu tanısı olan çocukların annelerinin psikolojik sıkıntı, travma sonrası gelişim ve yaşam doyumu düzeyleri ile ilgili değişkenler. (Yayımlanmamış yüksek lisans tezi). Dokuz Eylül Üniversitesi, Sosyal Bilimler Enstitüsü, İzmir.

\section{ORCID}

Mehmet YAVUZ https://orcid.org/0000-0003-0762-1611

Pınar ŞAFAK iD https://orcid.org/0000-0002-3386-9816 


\section{$S U M M A R Y$}

\section{Introduction}

Life satisfaction is a person's perception of his / her entire life as positive in accordance with the criteria determined by him / her (Veenhoven, 1991). According to Cummings and Nistico (2002), on the other hand, life satisfaction is a subjective evaluation of an individual obtained as a result of evaluating his/her life as a whole (Pavot \& Diener, 1993). The life satisfaction levels of the parents of individuals with disabilities are generally low (Akarsu, 2014) because the handicapped child greatly affects the life of the parents and places additional burden and responsibilities on the family. Some of these burdens are taking care of the disabled child, the change of home routines, the deterioration of the roles of family members, economic problems, additional hospital expenses and experiencing a decrease in monthly income (Ohaeri, 2003). In addition, as well as social support to the family, the family satisfaction decreases, emotional problems occur between parents, and their lifestyles change (Trute \& Hiebert-Murphy, 2002).

All of these can cause parents to get stressed, to have a decrease in their self-sufficiency levels and their life satisfaction as a result (Barlow, Powell, \& Gilchrist, 2006). Life satisfaction is a variable that affects all life activities of the individual. For this reason, if the life satisfaction levels of the parents of disabled children are known, necessary practices can be implemented to improve them if they are low or sustain their satisfaction levels high if they are already high. When parents' life satisfaction levels are high, they will be able to offer better life opportunities for both themselves and their children.

In this research, the answers to these questions were investigated:

1. What is the life satisfaction levels of the parents of children with intellectual disabilities, autism spectrum disorders and multiple disabilities?

2. Do parents' life satisfaction levels differ significantly in terms of parents' gender, age, education level, income level, the type of disability and the gender of their disabled children?

\section{Method}

The parents of 256 disabled children participated in the study in which general scanning model was employed. To collect data, Demographic Information Form and Life Satisfaction Scale developed by Diener, Emmons, Larsen and Griffin (1985) and adapted to Turkish by Dağll and Baysal (2016) were used. The research data were collected from the parents of the disabled individuals attending special education and rehabilitation centers in Edirne and Istanbul provinces. Independent samples t test, one-way ANOVA test and Tukey HSD test were used to analyze the data.

\section{Findings, Results, Discussion and Suggestions}

According to the results of the research, the life satisfaction of the parents was detected to be average. It is known that despite parents have an average level of life satisfaction, parents of disabled children have low life satisfaction, in general. The reason for this is that parents experience intense stress and depression due to reasons such as behavioral problems of their children, getting low social support, and poor marital adjustment because of the extra burden that the disabled child place on them. Such situations reduce the life satisfaction of parents.

No significant difference was detected in the life satisfaction of the parents in terms of the gender variable. The reason for not finding a significant difference in the life satisfaction of the parents 
in terms of the gender variable is that in general, the care burden of the disabled child is generally borne by mothers. On the other hand, it is the duty of the father to be the breadwinner. This situation may have increased the marital adjustment of the couples having a disabled child. Thus, it may have affected their life satisfaction positively.

There was no significant difference in the life satisfaction of the parents in terms of the age variable. The reason why there was no difference in the life satisfaction levels of the parents in terms of the age variable can be explained by the fact that at each age period, the disabled child brings different problems and burdens to the family.

As the education level of the parents increases, their life satisfaction also increases. This may be because education is related to both the income level and finding better educational opportunities for children with disabilities. A significant difference was observed in favor of those with high income. Income level is a variable that positively affects human life. Therefore, the difference in favor of individuals with a high level of income can be explained by their providing themselves and their children with more comfortable living opportunities. However, the life satisfaction levels of the parents did not differ significantly in terms of the child's disability type variable. Based on the findings of this study, it can be said that the type of the disability of the child affect the parents equally since the life satisfaction of the parents do not differentiate.

According to the results of this study, the life satisfaction level of the parents did not differ significantly regarding the gender of the disabled child, which can be explained by the parents' embracing their children regardless of their gender. 
Ek 1. Etik Kurul Onay Yazısı

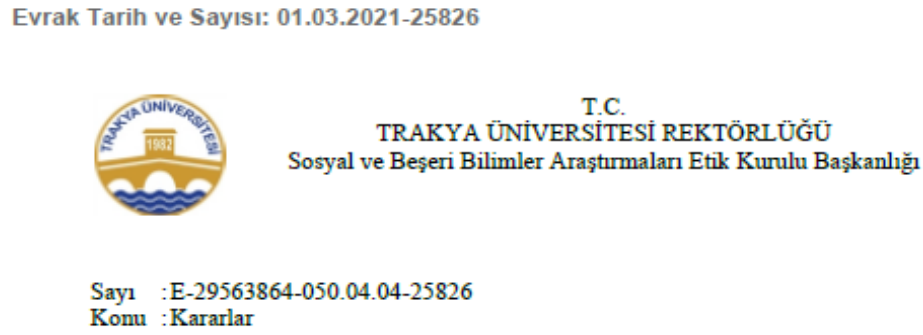

Say1 :E-29563864-050.04.04-25826

Konu :Kararlar

Sayın Dr. Öğr. Üyesi Mehmet YAvUZ

Yapmış olduğunuz araştırma ile ilgili başvununuz Trakya Üniversitesi Sosyal ve Beşeri Bilimler Araștırmalan Etik Kurulu'nun 24.02.2021 tarihli toplantısında alınan 02/14 numaralı kararı ile uygun görülmüşstür.

Gereğini bilgilerinize rica ederim.

Prof. Dr. Ayhan GENÇLER

Başkan

Ek: Etik Kurul Karan

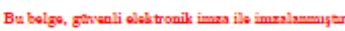

Bolge Doogrulama Kodu •BEENFKYCFZ* Pin Koda :42042

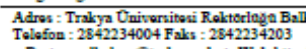

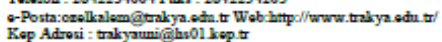

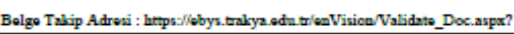

Bagi icin : Coyda DURSUN

Bu belge 5070 sayılı Elektronik imza Kanununun 5. Maddesi gereğince güvenli elektronik imza ile imzalanmıștır. 